\title{
Полный цикл разработки и производства современных охлаждаемых ИК ФПУ на основе КРТ в ИФП СО РАН
}

Ю.Г. Сидоров ${ }^{1}$, М.В. Якушев ${ }^{1}$, И.В. Сабинина ${ }^{1}$, Г.Ю. Сидоров ${ }^{1}$, В.В. Васильев ${ }^{1}$, Д.В. Марин ${ }^{1}$, С.А. Дворецкий ${ }^{1}$ Н.Н. Михайлов ${ }^{1}$, В.С. Варавин ${ }^{1}$, Д.Г. Икусов ${ }^{1}$, А.В. Зверев ${ }^{1}$, Ю.С. Макаров ${ }^{1}$, А.В. Предеин ${ }^{1}$, И.В. Марчишин ${ }^{1}$, А.В. Вишняков ${ }^{1}$, В.Г. Ремесник ${ }^{1}$, Д.В. Горшков ${ }^{1}$, А.В. Латышев ${ }^{1}$, П.А. Сысоев ${ }^{2}$, К.С. Лопаткин ${ }^{2}$

${ }^{1}$ ИФП СО РАН, Новосибирск, 630090, Лаврентьева, 13

${ }^{2}$ Филиал 46 ЦНИИ МО РФ, Мытищи МО, 141006

тел: (383)330-89-60, факс: (383)333-27-71, эл.nочта: george@isp.nsc.ru

DOI 10.34077/RCSP2021-15

Охлаждаемые детекторы ИК излучения являются незаменимыми в широком поле различных применений, включающих промышленное оборудование, военную и спецтехнику, аэрокосмические и метеорологические средства наблюдения. Приборы с наилучшими характеристиками изготавливаются на основе тройного раствора $\mathrm{Cd}_{\mathrm{x}} \mathrm{Hg}_{1-\mathrm{x}} \mathrm{Te}$ (КРТ), позволяющего за счет состава реализовать чувствительность во всем ИК диапазоне. Таким образом способность осуществлять разработку и создание приборов на основе КРТ является одним из критических условий для обеспечения государственной безопасности и технологического лидерства.

В последние десятилетия на базе ИФП СО РАН шло последовательное формирование пакета технологий, который на данный момент позволяет реализовать полный цикл разработки и изготовления охлаждаемых фотоприемных устройств (ФПУ) на основе КРТ для всех ключевых диапазонов ИК-спектра. В докладе рассказано об основных элементах данного цикла: выращивании гетероэпитаксиальных структур (ГЭС) КРТ на подложках из арсенида галлия и кремния методом молекулярно-лучевой эпитаксии (МЛЭ), технологии изготовления матриц фотодиодов различной топологии, проектировании современных кремниевых схем считывания, технологии гибридной сборки, разработки и изготовлении интегрально стыкуемых вакуумных криостатов, измерительных стендах.

Технология выращивания ГЭС КРТ методом МЛЭ развивалась в ИФП первой, в результате чего были созданы полностью отечественные ростовые установки, оснащенные эллипсометрическим контролем состава и источниками оригинальной конструкции. Достигнутый в данный момент уровень позволяет выращивать ГЭС КРТ на подложках из кремния или арсенида галлия с любым, заранее заданным профилем состава и легирования, что позволяет выращивать не только фоточувствительный материал под любой спектральный диапазон и конфигурацию фотодиодов, но и квантово-размерные структуры: топологические изоляторы и квантовые ямы.

Комбинация разработанных процессов мокрого и сухого типов позволяет создавать массивы фоточувствительных элементов на основе ГЭС КРТ практически любого формата с минимальным на данный момент размером пиксела $15 \times 15$ мкм. В зависимости от задачи диоды могут иметь разную полярность, а также изготавливаться по планарной или меза-технологии. В комбинации с гибкостью имеющейся технологии МЛЭ создается возможность создания практически любого типа фоточувствительных элементов на основе КРТ, включая высокотемпературные и двухцветные.

Одним из ключевых элементов фотоприемника является интегральная схема считывания сигнала (ИСС). В данный момент в ИФП сформирована группа специалистов по разработке ИСС, способная создавать современные схемы считывания, обладающие радиационной стойкостью, высокой кадровой частотой и соотношением сигнал/шум с шагом до 15 мкм. В докладе приводятся характеристики разработанных ИСС.

Технология гибридизации ИСС и фоточувствительного элемента, разработанная в институте, позволила решить проблемы непланарности крупных кристаллов и точности их соединения, что позволило успешно создать фотоприемники форматом до 2000х2000 с шагом 20 мкм, а также приемники с шагом до 15 мкм. Перспективным является также переход к гибридизации кристаллов с малым боковым зазором для мозаичных приемников, 3D-stacking и шаг элементов менее 15 мкм.

Завершающим этапом создания ФПУ является размещение в вакуумном криостатируемом корпусе (ВКК). В ИФП разработана универсальная линейка ВКК интегрально сопряженных с МКС разных типов - линейных, роторных и пульсационных. Это позволяет подбирать комбинацию МКС и криостата практически под любую задачу и применение.

В заключительной части доклада приведены параметры ФПМ форматов 4х288, 320x256, 384x288, $640 x 512,1024 x 1024,1500 x 1500$ и 2000x2000 изготовленных на основе ГЭС КРТ МЛЭ на подложках из кремния. 